\title{
Is peritoneal dialysis prior to kidney transplantation a risk factor for ureteral stenosis after adult to adult live kidney transplantation
}

Koray Kutlutürk ${ }^{1}(I D)$, Tevfik Tolga Şahin ${ }^{1}(I D)$, Serhan Çimen²(ID), Yasin Dalda ${ }^{1}\left(\right.$ ID), Fatih Gönültaş ${ }^{1}(I D)$, Sait Murat Doğan ${ }^{1}($ ID), Sibel Altunışık Toplu(ID), Bülent Ünal ${ }^{4}\left(\right.$ ID), Turgut Pişkin ${ }^{1}$ (ID)

\footnotetext{
${ }^{1}$ Department of General Surgery, Inonu University School of Medicine, Malatya, Turkey

${ }^{2}$ Clinic of Urology, Malatya Education and Research Hospital, Malatya, Turkey

${ }^{3}$ Department of Infectious Diseases and Clinical Microbiology, Inonu University School of Medicine, Malatya, Turkey

${ }^{4}$ Department of General Surgery, Eskisehir Osmangazi University School of Medicine, Eskisehir, Turkey
}

\section{ABSTRACT}

Objective: Major urinary complications such as urinary leaks, stenosis or urinary tract infections after kidney transplantation can lead to graft or patient loss. The effect of peritoneal dialysis on post-kidney transplantation complications have been discussed but its effect on ureteral stenosis is unknown. In this study, it was aimed to analyze factors effecting major ureteral complications after living donor kidney transplantation and impact of peritoneal dialysis and double J-stents (J stents).

Material and Methods: This study included 116 adult to adult living donor kidney transplant patients. Factors effecting major urologic complications after living donor kidney transplantation were analyzed. The donors were primary relatives of the recipients.

Results: Major urologic complications after living donor kidney transplantation was 8/116 (6.9\%). Urinary leak was present in 2 (1.7\%) patients. Ureteral stenosis was encountered in 6 (5.2\%) patients. Double J stents were used in 84 (72.4\%) of the cases. The effect of JJ ureteral stent was not statistically significant for urinary leak, ureteral stenosis ( $p=0.074, p=0.470$, respectively). A total of $29(25 \%)$ patients had peritoneal dialysis before kidney transplantation. Preoperative peritoneal dialyses and bacteriuria after kidney transplantation were independent risk factors for ureteral stenosis in multivariate analysis $(p=$ 0.013 , and $p=0.010$ respectively).

Conclusion: In the guidance of the results of the present study, peritoneal dialysis prior to kidney transplantation and bacteriuria are independent risk factors for ureteral stenosis after living donor kidney transplantation. JJ stents have no effect on urologic complications after living donor kidney transplantation.

Keywords: Renal transplantation, urologic complications, peritoneal dialysis, ureteral stenosis

Cite this article as: Kutlutürk K, Şahin TT, Çimen S, Dalda Y, Gönültaş F, Doğan SM, et al. Is peritoneal dialysis prior to kidney transplantation a risk factor for ureteral stenosis after adult to adult live kidney transplantation. Turk J Surg 2020 36 (1): $33-38$

Corresponding Author

Koray Kutlutürk

E-mail: kkutluturk@gmail.com

Received: 24.08.2019

Accepted: 26.09 .2019

Available Online Date: 18.03 .2020

O Copyright 2020 by Turkish Surgical Society Available online at www.turkjsurg.com

DOI: $10.5578 /$ turkjsurg. 4605

\section{INTRODUCTION}

Kidney transplantation is the definitive treatment option for patients with endstage renal disease. Major urinary complications such as urinary leaks, ureteral stenosis or urinary tract infections after kidney transplantation can lead to graft or patient loss and in different transplantation centers, its incidence varies from $2.5-14 \%(1-5)$. Ureterovesical anastomosis is the most frequent source of morbidity following kidney transplantation. Many ureterovesical anastomotic techniques are described: Intravesical Politano-Leadbetter (PL), the extravesical Campos Freire technique, better known as Lich-Gregoir (LG) and the Taguchi or U-stitch (U) technique. Current approaches show that LG ureterovesical anastomotic technique results in fewer post-operative urological complications (6). The main objective of the centers dealing with solid organ transplantation is to reduce surgical site complications in order to improve the success of transplantation (7). The impact of peritoneal dialysis before kidney transplantation on urinary complications after kidney transplantation is still a matter of debate, and there are many controversies regarding which strategy to use the double J (J) stents (8-17). 
The aim of this study was to analyze the factors effecting major urinary complications, especially ureteral stenosis, after living donor kidney transplantation. Furthermore, we analyzed the impact of preoperative peritoneal dialysis and JJ stents on ureteral stenosis following living donor kidney transplantation.

\section{MATERIAL and METHODS}

\section{Selection and Exclusion Criteria for the Patients}

Between November 2010 and April 2017, 149 adult to adult living donor kidney transplantations were performed in our center. After excluding 23 patients lost during follow up, 4 early deaths not related to urologic complications, 1 patient with double ureter anastomosis, and 4 grafts harvested laparoscopically from the donor; 116 patients were included for the evaluation in the study. The data of these patients were collected retrospectively from the electronic patient database. In our institution, living donors are first till fourth degree relatives of the recipients.

\section{Study Parameters and Definition of Urinary Complications}

All of the ureter anastomosis was performed with extravesical Lich-Gregoir thecnique (6). Age, sex induction immunosuppression protocols, graft type (left versus right), implantation area, total ischemia time, re-exploration on/any invasive procedure after transplantation within one month, use of JJ stents while performing ureteral anastomosis, dialysis status (peritoneal, hemodialysis or preemptive) and dialysis time before transplantation, intraoperative complications, suction drain use, postoperative urinary culture results, presence of urinary leak and stenosis were retrospectively collected and evaluated. Bacteriuria was defined as presence of $\geq 10^{5}$ colony forming unit of bacteria in the postoperative urinary culture taken in any time point. Patients who had increasing serum creatinine level, hydronephrosis in transplanted kidney in imaging and also those who required radiologic or surgical intervention were considered to have ureteral stenosis. In stented patients, the stents were removed 4-6 weeks after the operation. In all patients, urinary Foley catheter was removed 5 days after the operation.

\section{Postoperative Management Protocol}

Tacrolimus, mycophenolic acid and corticosteroids were used as maintenance immunosuppression after transplantation if there was no contraindication or adverse effect. Perioperative single dose $1 \mathrm{gr}$ cefazolin sodium was given intravenously for antimicrobial prophylaxis. Trimethoprim-sulfometaxazole was used for six months for pneumocystis carinii prophylaxis. Ureteral stenosis and urinary leaks were treated percutaneously as an initial management approach. In case of a failure, reoperation and ureteroneocystostomy was performed.

\section{Statistical Analysis}

Continuous variables were expressed as median and range. Discrete variables were expressed as the number of patients af- fected together with the percentage. The relationship between the dependent and independent variable was performed using parametric tests including chi-square test. Any $p$ value less than or equal to 0.05 was considered as statistically significant. Univariate and multivariate logistic regression analyses were performed in order to determine the risk factors for urologic complications. The variables that showed a p values less than 0.2 in univariate analysis were included in the multivariate analysis. All statistical evaluations were performed on Statistical Program for Social Sciences software v 20 (SPSS v20, IBM, USA).

Ethics Committee approval was received for this study from the Ethics Commiteee of Inonu University Health Sciences Non-interventional Clinical Research (Number: 2020/564, Date: 17.03.2020).

\section{RESULTS}

Median age of the patients 34.5 (20-40) and female/male ratio was 39/77 (0.5). Totally, 34 right kidney and 82 left kidney grafts were used.

The implantation site was explored in the early postoperative period in 12 patients. The causes of reoperation were hematoma in three patients, hemorrhage from renal artery anastomosis in one patient, retroperitoneal hemorrhage in one patient, and urinary leakage in one patient, renal vein anastomotic stenosis in one patient in whom fibrous bands were found to be responsible for the stenosis. Four patients were operated for oliguria or anuria, and no surgical pathology had been found. One patient with anuria was explored, and Doppler USG revealed reduced arterial flow of graft and renal artery anastomosis was re-performed. In another patient, cystoscopy was performed on postoperative $3^{\text {rd }}$ day and evacuation of the hematoma was performed. Percutaneous drainage catheter was placed in two patients due to postoperative lymphocele $(n=1)$ on postoperative $14^{\text {th }}$ day and implantation site hematoma $(n=1)$ on postoperative $25^{\text {th }}$ day. There was no statistically significant difference in the development of urologic complication amongst the patients with or without reoperation/interventional radiologic procedures $(p=0.187)$.

Major urologic complications after living donor kidney transplantation in our study group was 8/116 (6.9\%). Preoperative peritoneal dialysis was present in 29 (25\%) patients. JJ stents were used in 84 (72.4\%) cases. Demographic characteristics of the patients were similar in stented and non-stented patients. In one patient, the JJ stent perforated the renal pelvis of the renal graft at operation and primary repair was performed intraoperatively. In the postoperative follow up period, no complication was encountered due to this condition. Median Double j stent removal time was 33 (7-105) days following the operation which was performed by cystoscopy under sedation.

Urinary leak was observed in only 2 (1.7\%) patients during the study period. Both of them were in non-stented patients. One of them was diagnosed six days after operation. Reoperation was 


\begin{tabular}{|c|c|c|c|c|}
\hline & \multicolumn{2}{|c|}{ Ureteral stenosis } & \multicolumn{2}{|c|}{$p$} \\
\hline & Yes & No & Univariate & Multivariate \\
\hline Age [year, median (Range)] & $27[20-41]$ & $35[20-60]$ & 0.109 & \\
\hline $\begin{array}{l}\text { Sex (n, percent) } \\
\quad \text { Male } \\
\quad \text { Female }\end{array}$ & $\begin{array}{c}6(7.8 \%) \\
-\end{array}$ & $\begin{array}{l}71(92.2 \%) \\
39(100 \%)\end{array}$ & 0.096 & \\
\hline $\begin{array}{l}\text { Dialysis status ( } n \text {, percent) } \\
\quad \text { Peritoneal dialysis } \\
\text { Hemodialysis or preemptive }\end{array}$ & $\begin{array}{l}4(13.8 \%) \\
2(2.3 \%)\end{array}$ & $\begin{array}{l}25(86.2 \%) \\
85(97.7 \%)\end{array}$ & 0.034 & 0.013 \\
\hline Dialysis time (month) & $24(2-60)$ & $10(1-156)$ & 0.980 & \\
\hline Total ischemia time (min) & $85(66-115)$ & $97(63-204)$ & 0.202 & \\
\hline $\begin{array}{l}\text { Induction IS ( } \mathrm{n} \text {, percent) } \\
\text { ATG } \\
\text { Basiliximab }\end{array}$ & $\begin{array}{l}5(5.1 \%) \\
1(5.6 \%)\end{array}$ & $\begin{array}{l}93(94.9 \%) \\
17(94.4 \%)\end{array}$ & 1,000 & \\
\hline $\begin{array}{l}\text { Graft ( } \mathrm{n} \text {, percent) } \\
\text { Left } \\
\text { Right }\end{array}$ & $\begin{array}{l}5(6.1 \%) \\
1(2.9 \%)\end{array}$ & $\begin{array}{l}77(93.9 \%) \\
33(97.1 \%)\end{array}$ & 0.669 & \\
\hline $\begin{array}{l}\text { Graft artery number (n, percent) } \\
\quad 1 \\
\quad>1\end{array}$ & $\begin{array}{c}6(6.1 \%) \\
-\end{array}$ & $\begin{array}{l}93 \text { (93.9\%) } \\
17(100 \%)\end{array}$ & 0.590 & \\
\hline $\begin{array}{l}\text { Double J Stent (n, percent) } \\
\text { Yes } \\
\text { No }\end{array}$ & $\begin{array}{l}5(6.0 \%) \\
1(3.1 \%)\end{array}$ & $\begin{array}{l}79(94.0 \%) \\
31(96.9 \%)\end{array}$ & 1.000 & \\
\hline $\begin{array}{l}\text { Suction drain (n, percent) } \\
\text { Yes } \\
\text { No }\end{array}$ & $\begin{array}{l}3(6.5 \%) \\
3(4.3 \%)\end{array}$ & $\begin{array}{l}43(93.5 \%) \\
67(95.7 \%)\end{array}$ & 0.680 & \\
\hline $\begin{array}{l}\text { Reoperation or any invazive procedure (n, percent) } \\
\text { Yes } \\
\text { No }\end{array}$ & $\begin{array}{l}1(6.7 \%) \\
5(5.0 \%)\end{array}$ & $\begin{array}{l}14(93.3 \%) \\
96(95.0 \%)\end{array}$ & 0.573 & \\
\hline $\begin{array}{l}\text { Bacteriuria after transplantation ( } \mathrm{n} \text {, percent) } \\
\text { Yes } \\
\text { No }\end{array}$ & $\begin{array}{c}4(12.9 \%) \\
2(2.4 \%)\end{array}$ & $\begin{array}{l}27(87.1 \%) \\
83(97.6 \%)\end{array}$ & 0.043 & 0.010 \\
\hline Total (n, percent) & $6(5.2 \%)$ & $110(94.8 \%)$ & & \\
\hline
\end{tabular}

done and re-anastomosis performed with the placement of a $J$ J stent. The other patient was diagnosed on postoperative $16^{\text {th }}$ day and was treated with percutaneous nephrostomy catheter, and a JJ stent was placed later on. The effect of JJ ureteral stent was not statistically significant for urinary leak after living donor kidney transplantation $(p=0.074)$.

Factors effecting ureteral stenosis is summarized in Table 1. Ureteral stenosis was encountered in 6 (5.2\%) patients; 5/84 (6.0\%) in stented and 1/32 (3.1\%) in non-stented patients. JJ stent use did not have a significant effect on ureteral stenosis $(p=1.000)$. The number of ureteral stenosis in peritoneal dialysis patients was 4 (13.8\%) and in non-peritoneal dialysis patients was 2 (2.8\%) and it was statistically significant $(p=0.034)$. Median time between ureteral stenosis and transplantation was $5.7 \pm 1.4$ months. All of the patients who developed ureteral stenosis after transplanta- tion were males; however, sex was not a risk factor in statistical analyses $(p=0.096)$. Peritoneal dialysis before transplantation and bacteriuria in the urine culture after transplantation were independent risk factors for the development of ureteral stenosis in our study $(p=0.013, O R=21.574,95 \% C l=1.924-241.911$ and, $\mathrm{p}=0.010, \mathrm{OR}=23.876,95 \% \mathrm{Cl}=2.131-267.474$, respectively). As for the treatment of stenosis, three of the six patients with ureteral stenosis were treated with percutaneous nephrostomy and placement of $\mathrm{J} \mathrm{J}$ stent. The remaining three patients required ureteroneocystostomy.

\section{DISCUSSION}

Urinary leaks and ureteral stenosis are the two most common urological complications after renal transplantation and its incidence is reported between 2.5-14\% (1-5). It's a preventable cause of graft loss and necessary precautions should be taken by the 
physician. In our study, the incidence of major urologic complications was $6.9 \%$ and it was compatible with the literature.

The impact of ureteral stenting on postoperative urinary leak, ureteral stenosis and bacteriuria after kidney transplantation is still a matter of debate. Various studies discuss the impact of $J J$ ureteral stent on postoperative major urologic complications and bacteriuria after kidney transplantation (8-17). Some of the studies support the use of $\mathrm{J}$ stents in order to prevent major urologic complications $(10,11)$. On the other hand, other studies contradict routine use and suggest using $\mathrm{J} \mathrm{J}$ stents in selected cases to prevent urologic complications $(8,15,17)$. Our findings showed that there was no correlation between use of JJ stent and major urologic complications such as urinary leak or ureteral stenosis. A prospective randomized controlled trial by Tavakoli et al. has shown that JJ stenting reduced the early major complications following renal transplantation such as leakage and stenosis but they have found a higher incidence of urinary tract infections in the stented patients (12). Fayek et al. have found that JJ stenting had a significant impact on prevention of major urinary complications following renal transplantation using cadaveric organs, however they stated that JJ stenting did not have a significant effect on the complication rates following living donor kidney transplantation (14).

Incidence of urinary leak after kidney transplantation ranges $0 \%$ to $8.9 \%$ (18). We observed only two (1.7\%) urinary leaks after transplantation in our study. These two patients were in non-stented group but it was not statistically significant. This may be due to the small number of patients in whom urinary leakage was observed.

Pretransplant peritoneal dialysis and its effects on postoperative complications are discussed in many studies (19-22). These studies state that urologic complications are reported to be similar in peritoneal dialysis group and others. In our study, we found similar results as these studies when we analyzed the effects of pretransplant peritoneal dialysis on posttransplant major urologic complications. However, these studies did not specifically investigate the effects of peritoneal dialysis on ureteral stenosis. When we analyzed factors affecting ureteral stenosis after living donor kidney transplantation, we found that peritoneal dialysis before transplantation and bacteriuria after transplantation were independent risk factors. We speculate that inflammation or immunologic mechanisms due to peritoneal dialysis can affect posttransplant ureteral stenosis. The composition of peritoneal dialysis solutions and patients' attitude during dialysis affects the development of peritonitis following the procedure. Ayar et al. have stated that icodextrin-based regimens during peritoneal dialysis before kidney transplantation more frequently caused encapsulating peritonitis (23).

In the present study, we didn't find any association between graft artery number and ureteral stenosis after kidney trans- plantation as reported before in some other studies $(24,25)$. Effect of graft artery number on urologic complications after kidney transplantation is still controversial. Karam et al. and various other researchers have reported that multiple graft arteries is a one of risk factor for ureteral stenosis after renal transplantation (26-28).

Although various studies report male sex as a risk factor for post-transplant urinary stenosis, in the present study, we did not find male sex as a risk factor even if all the patients with stenosis were males $(1,29)$. This may be related with the patient volume of the study and with increasing number of patients a clear difference amongst the gender in terms of ureteral stenosis will be defined.

There is no significant impact of JJ stent on the development of ureteral stenosis or urinary leaks. In the guidance of the results of the present study, it is our suggestion that patients with post-transplant positive urinary cultures and/or a history of pre-transplant peritoneal dialysis have an increased risk of ureteral stenosis and therefore, attending physicians should take the necessary precautions. JJ stenting should be performed in selected high-risk patients or not be performed by centers which are early in the learning curve for living donor kidney transplantation. Prospective randomized trials are required in order to evaluate the effect of different peritoneal dialysis solutions on post-transplant urinary complications. Furthermore, the role of JJ stenting on post-transplant ureteral stenosis in a subgroup of patients with peritoneal dialysis should be evaluated.

Ethics Committee Approval: Ethics Committee approval was received for this study from the Ethics Commiteee of Inonu University Health Sciences Non-interventional Clinical Research (Number: 2020/564, Date: 17.03.2020).

Informed Consent: Informed concent from was obtained from all patients. Peer-review: Externally peer-reviewed.

Author Contributions: Concept - T.P., B.Ü., S.M.D., K.K., S.Ç., F.G., Y.D., T.T.Ş.; Design - T.P., B.Ü., S.M.D., K.K., S.Ç., F.G., Y.D., T.T.S.; Supervision - T.P., B.Ü., S.M.D., K.K., S.Ç., F.G., Y.D., T.T.Ş.; Materials - Y.D., T.P., B.Ü.; Data Collection and/ or Processing - Y.D., F.G., S.Ç.; Analysis and/or Interpretation - T.T.Ş., K.K., F.G.; Literature Review - S.Ç., K.K., T.T.Ş.; Writing Manuscript - K.K., Y.D., T.T.Ş; Critical Reviews - T.P., B.Ü., S.M.D., T.T.Ş.

Conflict of Interest: No conflict of interest was declared by the authors.

Financial Disclosure: The present study is not supported by any private or governmental funding.

\section{REFERENCES}

1. Sui W, Lipsky MJ, Matulay JT, Robins DJ, Onyeji IC, James MB, et al. Timing and predictors of early urologic and infectious complications after renal transplant: an analysis of a New York Statewide Database. Exp Clin Transplant 2018;16(6):665-70. [CrossRef]

2. Emiroğlu R, Karakayal H, Sevmiş S, Akkoç H, Bilgin N, Haberal M. Urologic complications in 1275 consecutive renal transplantations. Transplant Proc 2019;33(1-2):2016-17. [CrossRef] 
3. Davari HR, Yarmohammadi H, Malekhosseini SA, Salahi H, Bahador A, Salehipour M. Urological complications in 980 consecutive patients with renal transplantation. Int J Urol 2006;13(10):1271-5. [CrossRef]

4. Whang M, Yballe M, Geffner S, Fletcher HS, Palekar S, Mulgaonkar S. Urologic complications in more than 2500 kidney transplantations performed at the Saint Barnabas healthcare system. Transplant Proc 2011;43(5):1619-22. [CrossRef]

5. Neri F, Tsivian M, Coccolini F, Bertelli $R$, Cavallari $G$, Nardo B, et al. Urological complications after kidney transplantation: experience of more than 1000 transplantations. Transplant Proc 2009;41(4):1224-6. [CrossRef]

6. Alberts VP, Idu MM, Legemate DA, Laguna Pes MP, Minnee RC. Ureterovesical anastomotic techniques for kidney transplantation: a systematic review and meta-analysis. Transpl Int 2014;27(6):593-605. [CrossRef]

7. Sözen H, Onaran M, Özen O, Dalgıç A. Urologic complications after renal transplant: a single-center experience. Exp Clin Transplant 2017. [CrossRef]

8. Abrol N, Dean PG, Prieto M, Stegall MD, Taner T. Routine stenting of extravesical ureteroneocystostomy in kidney transplantation: a systematic review and meta-analysis. Transplant Proc 2018;50(10):3397404. [CrossRef]

9. Kırnap M, Boyvat F, Torgay A, Moray G, YIldırım S, Haberal M. Incidence of urinary complications with double J stents in kidney Ttransplantation. Exp Clin Transplant 2019;17(Supp/ 1):148-52. [CrossRef]

10. Mangus RS, Haag BW. Stented versus nonstented extravesical ureteroneocystostomy in renal transplantation: a meta-analysis. Am J Transplant 2004;4(11):1889-96. [CrossRef]

11. Bzoma B, Kostro J, Hellmann A, Chamienia A, Hac S, Debska-Slizien A et al. Ureteric stenting in kidney transplant recipients, gdansk centre experience, Poland. Transplant Proc 2018;50(6):1858-62. [CrossRef]

12. Tavakoli A, Surange RS, Pearson RC, Parrott NR, Augustine T, Riad HN. Impact of stents on urological complications and health care expenditure in renal transplant recipients: results of a prospective, randomized clinical trial. J Urol 2007; 177(6):2260-4. [CrossRef]

13. Harza M, Baston C, Preda A, Olaru V, Ismail G, Domnisor L, et al. Impact of ureteral stenting on urological complications after kidney transplantation surgery: a single-center experience. Transplant Proc 2014;46(10):3459-62. [CrossRef]

14. Fayek SA, Keenan J, Haririan A, Cooper M, Barth R, Schweitzer E, et al. Ureteral stents are associated with reduced risk of ureteral complications after kidney transplantation. Transplantation 2012;93(3):304-8. [CrossRef]

15. Dominguez J, Clase CM, Mahalati K, MacDonald A, McAlister V, Belitsky $P$, et al. Is routine ureteric stenting needed in kidney transplantation? A randomized trial. Transplantation 2000;70(4):597-601. [CrossRef]

16. Chordia P, Schain D, Kayler L. Effects of ureteral stents on risk of bacteriuria in renal allograft recipients. Transpl Infect Dis 2013;15(3):268-75. [CrossRef]
17. Kumar A, Verma BS, Srivastava A, Bhandari M, Gupta A, Sharma R. Evaluation of the urological complications of living related renal transplantation at a single center during the last 10 years: impact of the Double-J stent. J Urol 2000;164(3 Pt 1):657-60. [CrossRef]

18. Haberal M, Boyvat F, Akdur A, Kırnap M, Özçelik Ü, Yarbuğ Karakayalı F. Surgical complications after kidney transplantation. Exp Clin Transplant 2016;14(6):587-95. [CrossRef]

19. Che X, Yang $X$, Yan J, Yuan Y, Ma Q, Ying L, et al. Effects of pretransplant peritoneal vs hemodialysis modality on outcome of first kidney transplantation from donors after cardiac death. BMC Nephrol 2018;19(1):235. [CrossRef]

20. Debska-Slizien A, Bobkowska-Macuk A, Bzoma B, Moszkowska G, Milecka A, Zadroznyc D, et al. Paired analysis of outcomes after kidney transplantation in peritoneal and hemodialysis patients. Transplant Proc 2018;50(6):1646-53. [CrossRef]

21. Prasad N, Vardhan H, Baburaj VP, Bhadauria D, Gupta A, Sharma $R K$, et al. Do the outcomes of living donor renal allograft recipients differ with peritoneal dialysis and hemodialysis as a bridge renal replacement therapy? Saudi J Kidney Dis Transpl 2014,25(6):1202-9. [CrossRef]

22. Dipalma T, Fernandez-Ruiz M, Praga M, Polanco N, Gonzalez E, Gutierrez-Solis E, et al. Pre-transplant dialysis modality does not influence short- or long-term outcome in kidney transplant recipients: analysis of paired kidneys from the same deceased donor. Clin Transplant 2016;30(9):1097-107. [CrossRef]

23. Ayar Y, Ersoy A, Ocakoglu G, Gullulu E, Kagızmanlı H, Yıldız A, et al. Encapsulating peritoneal sclerosis in peritoneal dialysis patients after kidney transplantation. Transplant Proc 2018;50(1):160-4. [CrossRef]

24. Benedetti E, Troppmann C, Gillingham K. Short and long-term outcomes of kidney transplants with multiple renal arteries. Ann Surg 1995;221:406-10. [CrossRef]

25. El-Mekresh M, Osman Y, Ali-El-Dein B, El-Diasty T, Ghoneim MA. Urological complications after living-donor renal transplantation. BJU Int 2001;87(4):295-306. [CrossRef]

26. Karam G, Hetet JF, Maillet F, Rigaud J, Hourmant M, Soulillou JP, et al. Late ureteral stenosis following renal transplantation: risk factors and impact on patient and graft survival. Am J Transplant 2006;6(2):352-6. [CrossRef]

27. Rahnemai-Azar AA, Gilchrist BF, Kayler LK. Independent risk factors for early urologic complications after kidney transplantation. Clin Transplant 2015;29(5):403-8. [CrossRef]

28. Fuller TF, Deger S, Büchler A, Roigas J, Schönberger B, Schnorr D, et al. Ureteral complications in the renal transplant recipient after laparoscopic living donor nephrectomy. Eur Urol 2006;50(3):535-41. [CrossRef]

29. Englesbe MJ, Dubay DA, Gillespie BW, Moyer AS, Pelletier SJ, Sung RS, et al. Risk factors for urinary complications after renal transplantation. Am J Transplant 2007;7(6):1536-41. [CrossRef] 


\section{ORIJINAL ÇALIŞMA-ÖZET}

Turk J Surg 2020; 36 (1): 33-38

\section{Böbrek nakli öncesi periton diyalizi erişkin canlı vericili böbrek nakli sonrası üreteral stenoz için risk faktörü müdür?}

Koray Kutlutürk ${ }^{1}$, Tevfik Tolga Şahin ${ }^{1}$, Serhan Çimen ${ }^{2}$, Yasin Dalda ${ }^{1}$, Fatih Gönültaş ${ }^{1}$, Sait Murat Doğan ${ }^{1}$, Sibel Altunışık Toplư ${ }^{3}$, Bülent Ünal ${ }^{4}$, Turgut Pişkin ${ }^{1}$

1 İnönü Üniversitesi Tıp Fakültesi, Genel Cerrahi Anabilim Dalı, Malatya, Türkiye

2 Malatya Eğitim ve Araştırma Hastanesi, Üroloji Kliniği, Malatya, Türkiye

3 Inönü Üniversitesi Tıp Fakültesi, Infeksiyon Hastalıkları ve Klinik Mikrobiyoloji Anabilim Dalı, Malatya, Türkiye

${ }^{4}$ Eskişehir Osmangazi Üniversitesi Tıp Fakültesi, Genel Cerrahi Anabilim Dalı, Eskişehir, Türkiye

\section{ÖZET}

Giriş ve Amaç: Böbrek nakli sonrası oluşan üriner kaçak, üreteral darlık veya idrar yolu infeksiyonları gibi majör ürolojik komplikasyonlar greft veya hasta kaybına neden olabilir. Periton diyalizinin böbrek nakli sonrası komplikasyonlar üzerine etkisi tartışıııştır ancak üreteral darlık üzerindeki etkisi bilinmemektedir. Bu çalışmada, canlı vericili böbrek nakli sonrası majör ürolojik komplikasyonlara etki eden faktörleri ve periton diyalizi ve double J-stentlerin (JJ stentler) etkisini analiz etmek amaçlanmıştır.

Gereç ve Yöntem: Bu çalışma canlı vericili böbrek nakli yapılan 116 hastayı içermektedir. Çalışmada, canlı vericili böbrek nakli sonrası majör ürolojik komplikasyonları etkileyen faktörler analiz edildi. Donörler, alıcıların birincil akrabaları idi.

Bulgular: Canlı vericili böbrek nakli sonrası majör ürolojik komplikasyonlar 8/116 (\%6,9) idi. İki $(\% 1,7)$ hastada üriner kaçak, $6(\% 5,2)$ hastada üreteral darlık saptanmış, $84(\% 72,4)$ olguda JJ stent kullanılmıştır. Üriner kaçak, üreteral darlık açısından JJ stent kullanımının istatistiksel olarak anlamlı bir etkisi saptanmamıştır ( $p=0,074, p=0,470)$. Toplam 29 (\%25) hastada böbrek nakli öncesi periton diyalizi öyküsü vardı. Preoperatif periton diyalizi ve böbrek nakli sonrası bakteriüri, multivaryant analizde üreteral darlık için bağımsız risk faktörleri olarak saptanmıştır $(p=0,013$ ve $p=0,010$ ).

Sonuç: Bu çalışmanın sonuçlarında canlı vericili böbrek nakli öncesi hastalarda periton diyalizi öyküsünün ve nakil sonrası bakteriürinin olması nakil sonrası üreteral darlık için bağımsız risk faktörleri olarak saptanmıştır. Canlı vericili böbrek nakli sonrası ürolojik komplikasyonlar üzerine JJ stentlerin etkisi saptanmamıştır.

Anahtar Kelimeler: Böbrek nakli, ürolojik komplikasyonlar, periton diyalizi, üreteral darlık

Doi: $10.5578 /$ turkjsurg.4605 